\title{
Practical Approach for Elements within Incorporated Charged Zinc Particles in an Anode Zinc Reactor of a Fabricated Zinc Bromine Battery Cell System ( $\left.\mathrm{ZnBr}_{2}\right)$ with Fitting Materials
}

\author{
Ibitoye Adelusi*๑, Fabrice Andrieux® and Richard Dawson® \\ Department of Engineering, Lancaster University, Lancaster, UK
}

Submission: February 22, 2021; Published: March 05, 2021

*Corresponding author: Ibitoye Adelusi, Department of Engineering, Lancaster University, Lancaster, UK,

Email: ibitoyea@hotmail.com, i.adelusi@lancaster.ac.uk

\begin{abstract}
Batteries with different chemistries and designs encounter various (redox reactions) to store energy through applying charges and discharges rates. Redox flow batteries systems such as zinc bromine batteries cells systems $\left(\mathrm{ZnBr}_{2}\right)$ can be enclosed with high surface area anode electrodes (reactors) and charged with some amount of added carbon particles for zinc deposition. The electrochemical reactions within a fabricated $\mathrm{ZnBr}_{2}$ battery cell system have been investigated with the coupled inlets and outlets brass fitting materials $(15 \mathrm{~mm}$ and $30 \mathrm{~mm})$ of different anode and cathode electrolyte compositions. SEM analysis was explored on some charged particles collected from the anode reactor to identify all the existing elements within the deposited charged zinc particles after several charges. The investigated zinc particles were between 254 microns to 354 microns. The electrolyte composition includes 3 moles of $\mathrm{KBr}$ (535.51 grams), 1 mole of $\mathrm{KCl}$ (111.89 grams) as the cathode side electrolyte and 3 moles of $\mathrm{ZnBr}_{2}$ ( 675 grams), 1 mole of $\mathrm{ZnCl}_{2}$ (205 grams), and $1 \mathrm{M}$ of $\mathrm{KCl}$ (111.826 grams) as the anode electrolyte solution. Originally, this journal paper has discovered the importance of coupling chemically resistance materials to $\mathrm{ZnBr}_{2}$ cells as investigated on the fabricated $\mathrm{ZnBr}_{2}$ cell that was initially converted to a CuZn $n_{2}$ battery cell system and reverted to the ideal $\mathrm{ZnBr}_{2}$ cell system before using an SEM technique to identify separately the present elements.
\end{abstract}

Keywords: SEM Analysis on Elements; Flow Rate; Reverting Battery Cell System

\section{Introduction}

As previously presented in a journal titled (Practical Development of a ZnBr2 Flow Battery with a Fluidized Bed Anode Zinc-Electrode), Journal of the Electrochemical Society, Volume 167, Number 5, various categories of anode reactors designed in solidwork were numerically examined before choosing the best candidate reactor and later passed different coulombs of charges and discharges to the fabricated $\mathrm{ZnBr}_{2}$ battery cell after the incorporated chosen reactor to the cell anode side and later explored the presented SEM analysis carried out in this paper on some particles collected from the anode reactor [1].

The fluent version in Ansys has assisted to successfully modelled a fluidized bed to address problems facing zinc-bromine battery cells systems. Such as dendrites problems within the cell; puncturing membranes of these cells systems and thereby resulting to cut off voltages, short circuits that also reduces their life span. Introducing and modelling a fluidized bed zinc electrode has demonstrated fast deposition of zinc ions within the battery system zinc electrode and serve as an incorporated alternative electrode to prevent depositing zinc ions onto a solid electrode previously making $\mathrm{ZnBr}_{2}$ cells to encounter mechanical abrasion and deteriorating the electrodes as zinc ions stays longer on them than the expected time [1-3]. See the presented schematic diagram in Figure 1.

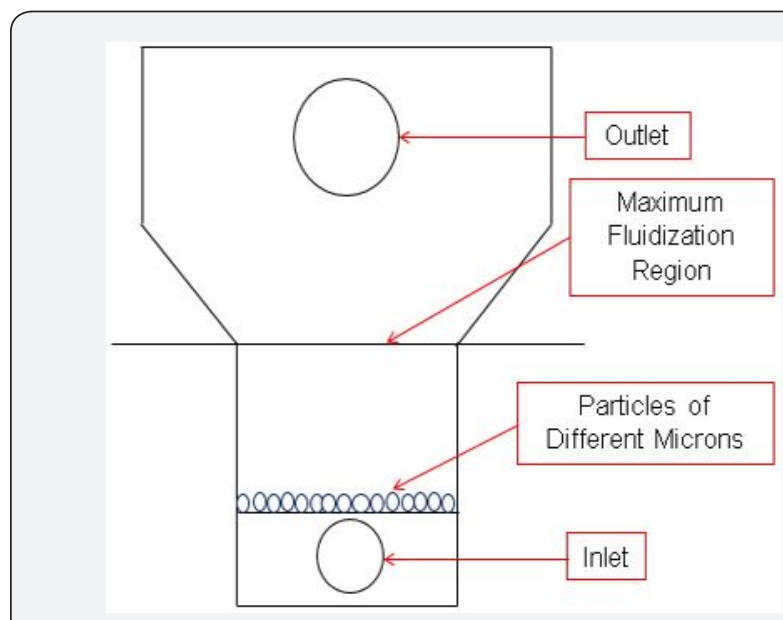

Figure 1: Sketched Diagram of the Reactor [1]. 


\section{Introduction to SEM and Fluidized Bed Reactors}

SEM (scanning electrons microscopy) and fluidized bed zinc anode reactors has several benefits. Some of these benefits include using SEM to examine electrode sample homogeneity and fluidized bed reactors for multiphase mixing purposes etc. Elements present within injected particles to zinc bromine batteries cells systems; anode zinc electrode can be examined using SEM analysis. Redox flow batteries cells systems (RFB's) such as zinc bromine batteries cells systems enclosed with high surface area zinc electrodes are capable to prevent the issue of dendrite formation within these batteries cells systems.

By means of SEM, scanning of electrons microscopy, samples images sample can be produced through focusing on the beam of electrons [4]. Anode zinc reactors of $\mathrm{ZnBr} 2$ batteries cells systems are usually in liquid and solid phases. Both the two phases, liquid and solid are common in petrochemical industries, biological industries in chemical industries and particularity for adsorption, cracking (catalytic), crystallization and for ion exchange [5] etc. Particles sizes and shapes within anode reactors has huge impact to achieve fluidization and prevent dendrite formation in $\mathrm{ZnBr}_{2}$ cells. However, majority of these fluidized beds are not always designed properly before fabrication and to tailoring them to the mean particle size; especially for those in use for particle size distributions [6-18].

Particles behaviour are now usually modelled using the DEM technique, (discrete element method). DEM approaches are used to represent particles numerically and individually by identifying them with their specific properties (shapes, magnitude, properties of their material and the original velocity) [19-21]. The geometry interior shape accommodating all the injected particles are the domain for the simulation. Designed reactors can be separated by grids to identify the positions of particles prior to modelling and simulating.

Based on Newton's laws, injected particles in reactors are subjected to have good contacts and can be exposed to a small motion during the iteration process [22-24]. Contacts among injected particles in a $\mathrm{ZnBr}_{2}$ anode reactor can be monitored throughout discrete reactions, modelling stages and to determine the particles contact forces ad magnitude through a spring dashpot model. The acceleration of drag forces on fluid and particles, total forces and summation can be computationally balanced before determining individually the parameters and particles motion [25].

Particles properties, such as structure can differently be observed using SEM, scanning of electrons microscopy and their sample compositions, and any interacted atoms within the provided sample [26,27]. In most application, over the surface of samples, data collections are possible within the selected area and spatially displayed variances in their properties. Areas in between $1 \mathrm{~cm}$ to 5 microns can be imaged using such technique and within a spatial resolution of 50 to $100 \mathrm{~nm}$ through using conventional scanning electrons microscopy method [28-31].

Suitable qualitative approaches, semi-quantitative, structural crystal or using EBSD to observe the orientation of the crystal and selecting point on samples are possible on SEM to determine chemically various compositions by means of an energy dispersive x-ray spectroscopy (EDS) [29,32]. Typically, scanning electron microscopy, as probes electrons micro-analyzer, EPMA, has considerably several existing designed functions of overlapped capabilities among other analytical instruments.

Backscattered electrons can be standardly collected using an SEM and electrons sources are the basic part of SEM. Through SEM analysis, electron's properties, electrodes dispersion and their homogeneity can also be observed [33,34]. The sources of electrons, high voltages encountered across them, electrons accelerating toward the samples, electromagnetic lenses, temperatures, detectors, and data systems collections are diffractions of samples usually at high incidence angles [35-40]. Within a user interface, SEM does not rely on a $2 \theta$ angle, rather to act marginally and similarly to a light microscope [41]. Some SEMs are equipped to count samples, detect, and analyze off a scattered x-ray. Through such type of detectors, the elemental composition of a sample can possibly be determined [42-44]. Table 1 has further presented other advantages and disadvantages of scanning electrons microscopy, SEM.

Table 1: SEM Advantages and Disadvantages.

\begin{tabular}{|c|c|c|}
\hline 1 & Advantages & Disadvantages \\
\hline 1 & $\begin{array}{c}\text { SEM produces images in a } \\
\text { three-dimensional way for imag- } \\
\text { es various cellular arrangement } \\
\text { to be shown and compare them } \\
\text { to light microscopes [53]. }\end{array}$ & $\begin{array}{c}\text { SEM device is equipment is } \\
\text { very expensive and requires } \\
\text { high degree of skills with } \\
\text { appropriate trainings. }\end{array}$ \\
\hline 2 & $\begin{array}{c}\text { The resolution is by 0.2nm more } \\
\text { than a light microscope [54]. }\end{array}$ & $\begin{array}{c}\text { Placing SEM samples in a vac- } \\
\text { uum is essential due to the } \\
\text { deflecting electrons beams in } \\
\text { the air by molecules. }\end{array}$ \\
\hline 3 & $\begin{array}{c}\text { Images can be produced in more } \\
\text { detailed by an electron micro- } \\
\text { scope. }\end{array}$ & $\begin{array}{c}\text { The production of Images is } \\
\text { usually black and white and } \\
\text { can only be falsely coloured. }\end{array}$ \\
\hline
\end{tabular}

Materials and Suppliers

\section{Materials and Method}

\section{SEM Preparation}

By exploring scanning of electrons microscopy (SEM) on some of the collected charged particles from the anode zinc reactor was to discover all the enclosed various elements after charging and discharging the zinc bromine battery cell at different charge rates. Before exploring SEM analyses on the charged deposited zinc morphology collected from the anode reactor were dried in an oven at a temperature of $50^{\circ} \mathrm{C}$ to prevent these particles from agglomerating together. 
The investigated particles sizes were in between (254 microns to 354 microns). Some of these particles from the anode-side zinc electrode after charging the cell were viewed at different microns (100 microns, 50 microns, 10 microns and 5 microns) by using the JEOL JSM-6010 PLUS/LA (SEM) scanning electron microscope machine.

The SEM characterization of the zinc electrodeposits were examined after charging the cell at a charge rate of 0.27 amps and 0.3 amps. The anode-electrolyte composition includes 3 moles of $\mathrm{ZnBr}_{2}$ (675 grams) Solution, 1 mole of $\mathrm{ZnCl}_{2}$ (205 grams), and 1 mole of $\mathrm{KCl}$ (111.826 grams). The cathode electrolyte solution includes 3 moles of $\mathrm{KBr}$ (535 grams) and 1 mole of $\mathrm{KCl}$ (111.897 grams). The anode electrolyte solution density was $1.47 \mathrm{~g} \mathrm{~cm}^{-3}$ which was used to gauge the cathode-electrolyte. A flow rate of $\left(166.7 \mathrm{~cm}^{3} / \mathrm{min}\right)$ was maintained throughout the experiment. The used JSM-6010LA/JSM-6010LV equipment for the scanning process was a compact mobile SEMs device with high performance and suitable for research use (Figure 2). The surface structures are observed by secondary electrons, the distribution of materials in a specimen was observed by backscattering the electrons and analysing the elements by EDS (energy dispersive X-ray analyser). All the necessary functions are available in the all-in-one mobile multi-touch-panel SEM [45-49].

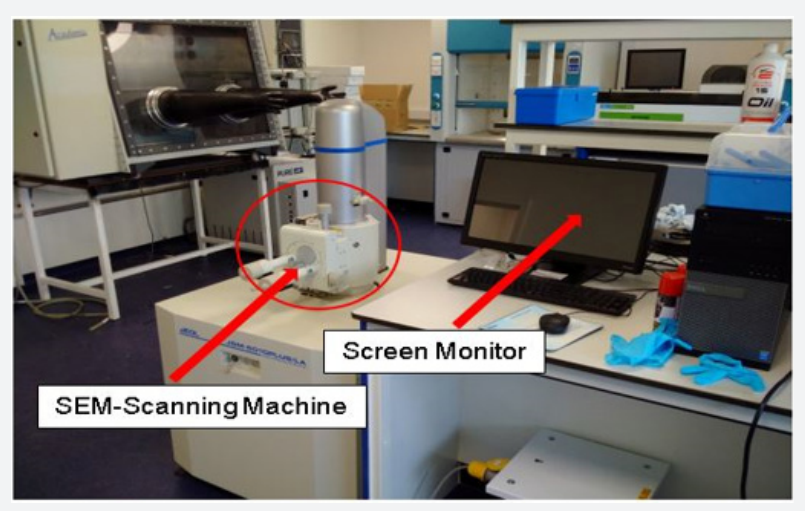

Figure 2: Lancaster University JEOL JSM-601 OPLUS/LA analytical scanning electron microscope machine.

Results Analysis and Discussion

\section{Examined Particles}

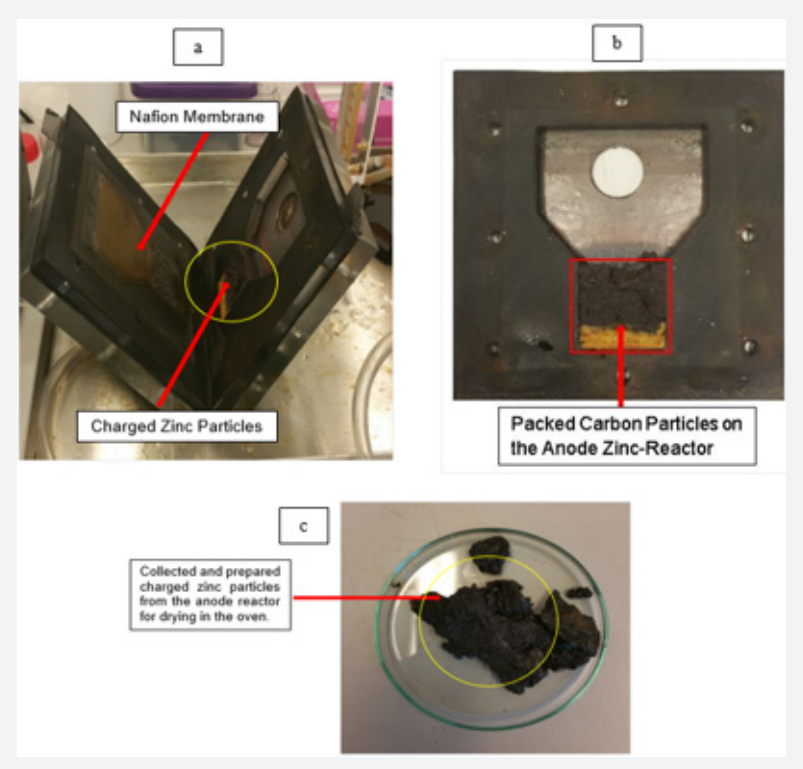

Figure 3:

a) The pulled apart $\mathrm{ZnBr} 2$ battery cell with the incorporated charged zinc particles.

b) The anode reactor.

c) Charged and collected zinc particles prepared and transferred to the oven to dry before the explored SEM on the particles. 
Particles collected from the anode zinc reactor in the lab for SEM analysis (scanning of electrons image) occupied some white edges after the charge and discharge experiments according to the colour mapping. (Figures 3a-3c) for the decoupled anode and cathode cell reactor, the anode zinc reactor incorporating charged zinc particles, the collected and prepared charged electrodeposited zinc morphology enclosed within the small glass coin beaker for SEM analysis. Encountered degasification, the removal of dissolved gases from the anode and cathode electrolyte solution was due to the solid and liquid interfaces enclosing some formed bubbles during the experimental work. The observed degasification was concluded to have originated from particles that were not properly dried before removing them from the oven and before the SEM process. Particles not properly dried before the SEM analysis were expected to have strangely behaved and

Table 2: Anode and Cathode Materials for the Explored Experiment. changed the zinc morphology (shape and structure) due to the observed gasification.

The dried and examined zinc morphologies presented in Figures 4-6 were studied using the scanning of electron microscopy, SEM characterization to observe elements enclosed within these particles after the redox reaction (charged and discharged) to store and discharge the stored energy by the fabricated zinc bromine battery cell and after observing copper deposits at the cathodeside electrolyte due to the brass fittings that were not chemically resistance that initially changed the battery to a copper-zinc RFB cell before it was reverted back to a zinc-bromine battery cell by changing some of the materials. See the two graphical peak plots in Figure $7 \mathrm{a} \& 7 \mathrm{~b}$ for the identified copper showing the presence of copper at a wavelength of $740 \mathrm{~nm}$ and at a wavelength of $900 \mathrm{~nm}$ with a UV-visible spectrophotometer device (Table 2).

\begin{tabular}{|c|c|c|}
\hline \multicolumn{3}{|c|}{ Purchased Materials for the Anode and Cathode Compartment } \\
\hline Purchased Chemicals & Comment & The Suppliers \\
\hline $\begin{array}{l}\text { Graphite powder, }-20+80 \text { mesh, } 99.9 \% \text { (met- } \\
\text { als basis) } 1 \mathrm{~kg}\end{array}$ & $\begin{array}{l}\text { Graphite powder was added to the anode reactor and } \\
\text { charged for the electrodeposition of zinc morphology. }\end{array}$ & Alfa Aesar \\
\hline $\begin{array}{l}\text { Azlon }^{\mathrm{TM}} \text { Square HDPE Carboys with Stopcock } \\
\text { 5L }\end{array}$ & Cathode and anode reservoir tank & Fisher Scientific \\
\hline $\begin{array}{l}\text { Black Neoprene Rubber Sheets } 1000 \mathrm{~mm} \text { x } \\
\qquad 2000 \mathrm{~mm} \text { x } 1.5 \mathrm{~mm}\end{array}$ & $\begin{array}{l}\text { Rubber material was enclosed as gaskets } \\
\text { (190mm*190mm*0.1 mm) to the cell avoid unwanted } \\
\text { leakage. }\end{array}$ & RS Components \\
\hline $\begin{array}{l}\text { RS Pro HDPE Laboratory Bottle with Narrow } \\
\text { Neck, 5L }\end{array}$ & $\begin{array}{l}\text { Material was purchased to replace the damaged cath- } \\
\text { ode tank because of bromine formation. }\end{array}$ & RS Components \\
\hline $\begin{array}{l}\text { Gear Wrench } 8 \times 10 \mathrm{~mm} \text { Offset Ring Spanner } \\
185 \mathrm{~mm} \text { length }\end{array}$ & $\begin{array}{l}\text { Sprouted socket spanners mounted on the cell for } \\
\text { tightening the bolts and nuts }\end{array}$ & RS Components \\
\hline $\begin{array}{l}\text { Nafion }^{\mathrm{TM}} \text { Membrane N324, Teflon Fabric Rein- } \\
\text { forced Gewebeverstärkt }\end{array}$ & $\begin{array}{l}\text { Materials was purchased to prevent the anode and } \\
\text { cathode electrolyte from mixing. }\end{array}$ & $\begin{array}{l}\text { Ion Power, Uber uns, AGB, Datenschutz- } \\
\text { bestimmungen }\end{array}$ \\
\hline $\begin{array}{l}\text { RS Pro PET, PVC transparent Flexible Tube } \\
\text { 25m, Long Reinforced, 60mm Bend Radius, } \\
\text { Application, various }\end{array}$ & $\begin{array}{l}\text { Material was purchased and coupled to the cell } \\
\text { to transfer electrolyte into the anode and cathode } \\
\text { reactor. }\end{array}$ & RS Components \\
\hline $\begin{array}{l}\text { Carbon Fibre Sheet, } 300 \mathrm{~mm} \times 300 \mathrm{~mm} \times 0.75 \\
\mathrm{~mm} \text { (Carbon anode and cathode) }\end{array}$ & $\begin{array}{l}\text { The first invested feeder electrode. The material was } \\
\text { fabricated to this size: } 190 \mathrm{~mm} * 190 \mathrm{~mm} * 0.1 \mathrm{~mm} \text {. }\end{array}$ & RS Components \\
\hline $\begin{array}{l}\text { Carbon Fibre Sheet, } 300 \mathrm{~mm} \times 300 \mathrm{~mm} \times 0.75 \\
\mathrm{~mm} \text { as the cathode feeder electrode } \\
\text { Nickel Material as the anode feeder electrode }\end{array}$ & $\begin{array}{l}\text { The anode coupled nickel material size was } \\
\text { (190mm*190mm*0.1mm) and the carbon feeder elec- } \\
\text { trode was enclosed as the cathode feeder electrode. }\end{array}$ & $\begin{array}{l}\text { The carbon fibre sheet was purchased } \\
\text { from RS component and the nickel mate- } \\
\text { rial was supplied by Lancaster university } \\
\text { supervisor. }\end{array}$ \\
\hline $\begin{array}{c}\text { Nickel Material as the anode feeder electrode } \\
\text { Titanium Material as the cathode feeder } \\
\text { electrode. }\end{array}$ & $\begin{array}{l}\text { The anode coupled nickel material size was } \\
\left(190 \mathrm{~mm}^{*} 190 \mathrm{~mm}^{*} 0.1 \mathrm{~mm}\right) \text { and the titanium feeder } \\
\text { electrode was enclosed as the cathode feeder elec- } \\
\text { trode. }\end{array}$ & $\begin{array}{c}\text { A technology company supplied was } \\
\text { the titanium sample. The nickel feeder } \\
\text { electrode was supplied by the Lancaster } \\
\text { university supervisor. }\end{array}$ \\
\hline RS Pro Plain Nylon Threaded Bar, M8, 1m & The threaded bar carries the weight of the battery cell. & RS Components \\
\hline Nylon, Hex Nut Natural, M8 & $\begin{array}{c}\text { The material was mounted on the purchased treaded } \\
\text { bar and tightened to prevent leakages. }\end{array}$ & RS Components \\
\hline $\begin{array}{l}\text { M8 Plain Nylon Sealing Washer, 2mm Thick- } \\
\text { ness }\end{array}$ & $\begin{array}{l}\text { The material was mounted on the cell before the pur- } \\
\text { chased treaded bar was mounted and tightened. }\end{array}$ & RS Components \\
\hline $\begin{array}{c}\text { Klinger Statite } 2000 \times 1000 \mathrm{~mm} 1.5 \mathrm{~mm} \text { Thick } \\
\text { Beige, Gasket Sheet, Statite, Maximum of } \\
+120^{\circ} \mathrm{C}\end{array}$ & $\begin{array}{l}\text { The material was purchased to replace the initial fab- } \\
\text { ricated rubber gaskets that cannot prevent leakages. }\end{array}$ & RS Components \\
\hline
\end{tabular}




\section{Trends in Technical \& Scientific Research}

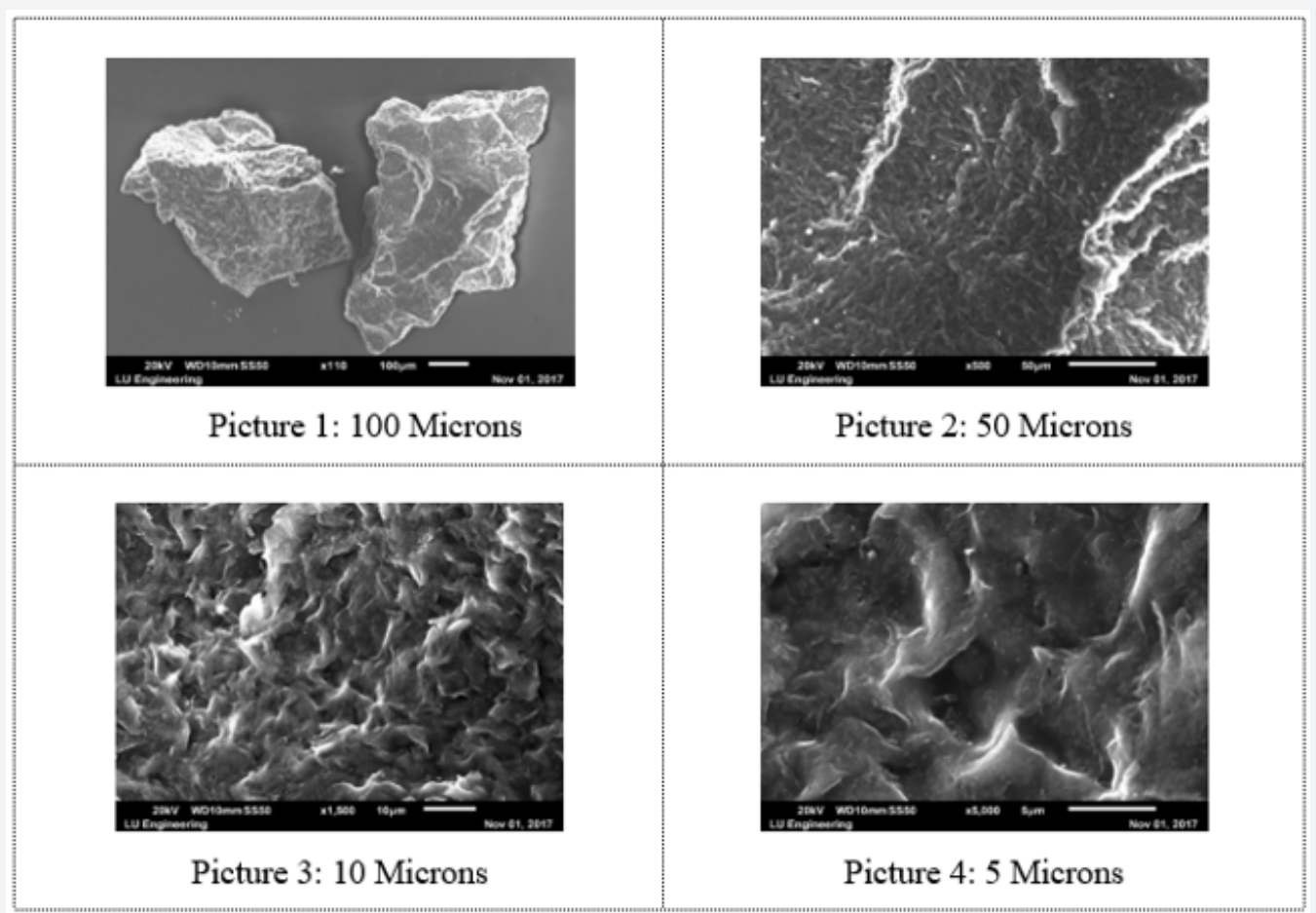

Figure 4: Charged Dried Particle.

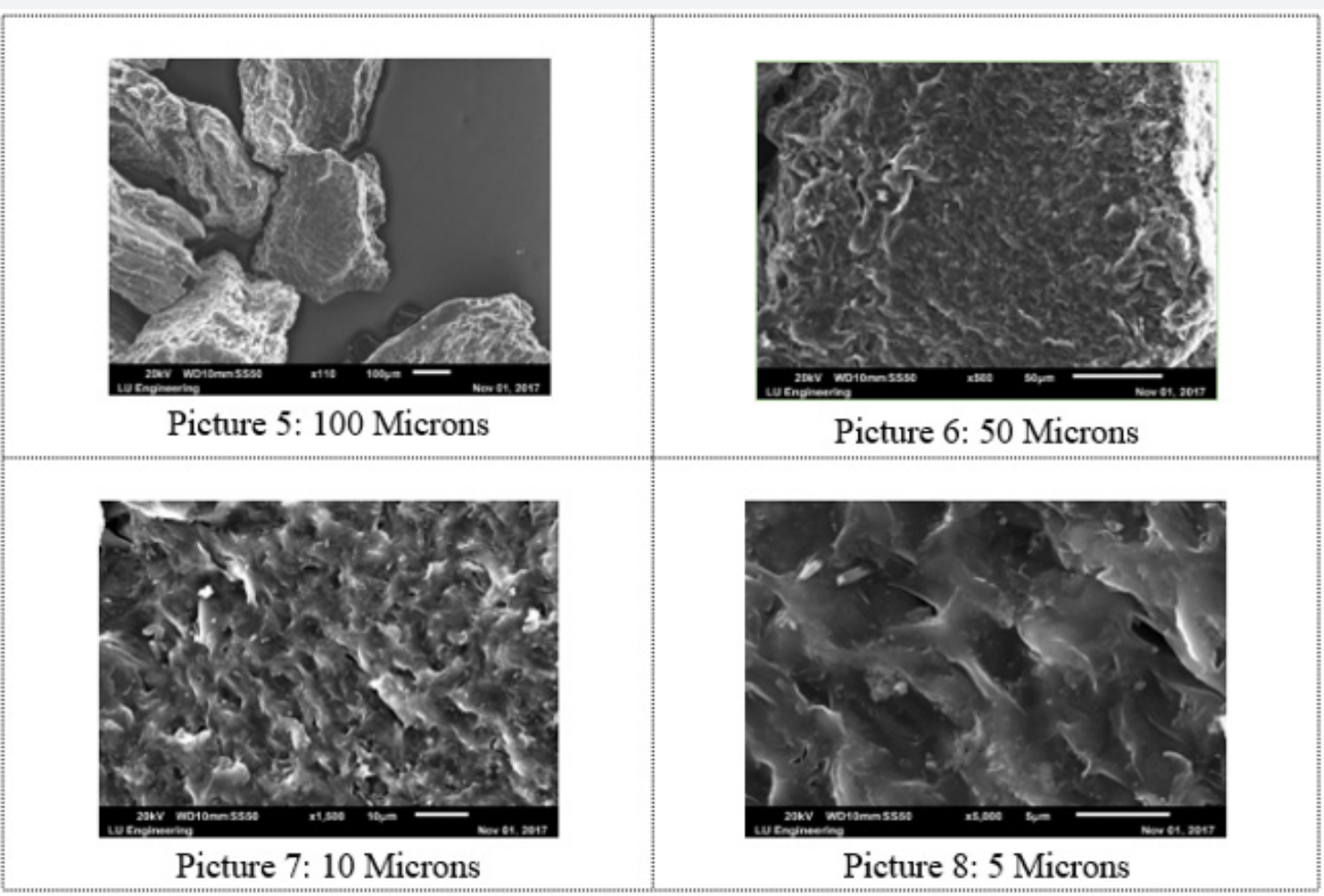

Figure 5: Discharged Dried Particles. 


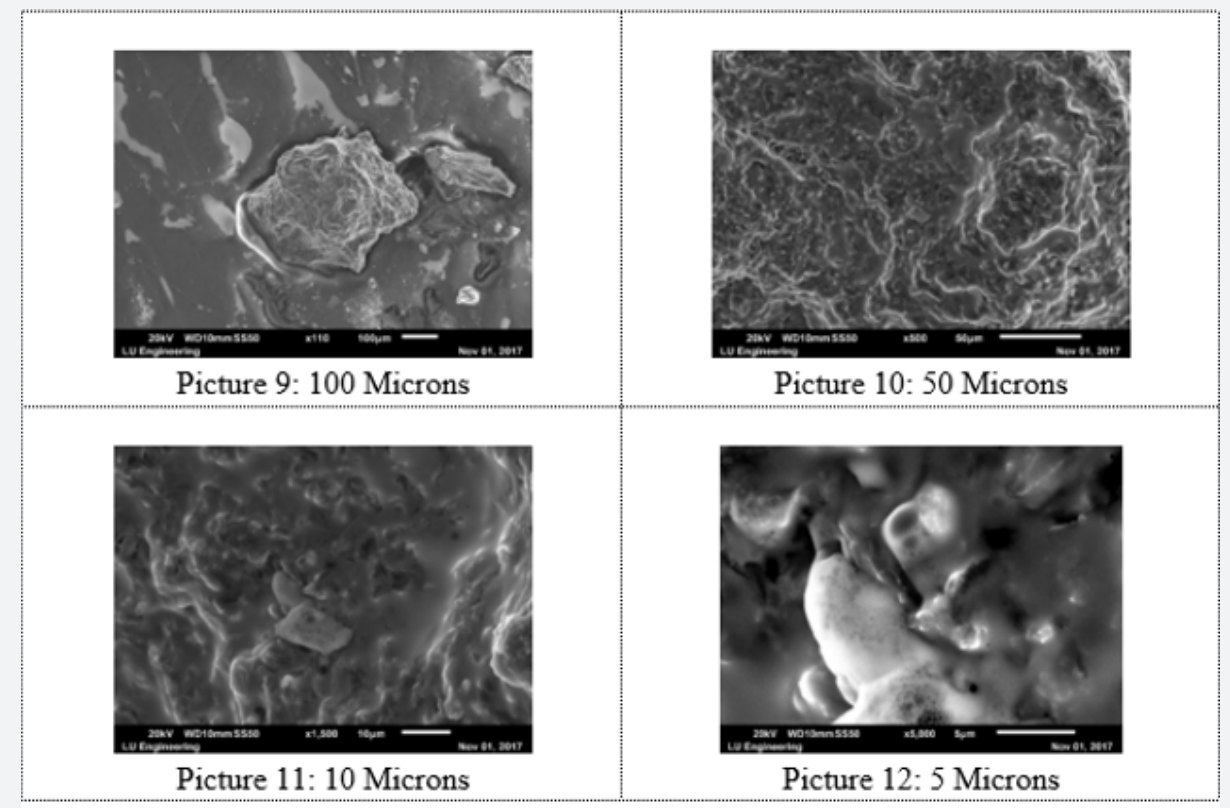

Figure 6: Copper Deposits During Charging and Discharging.

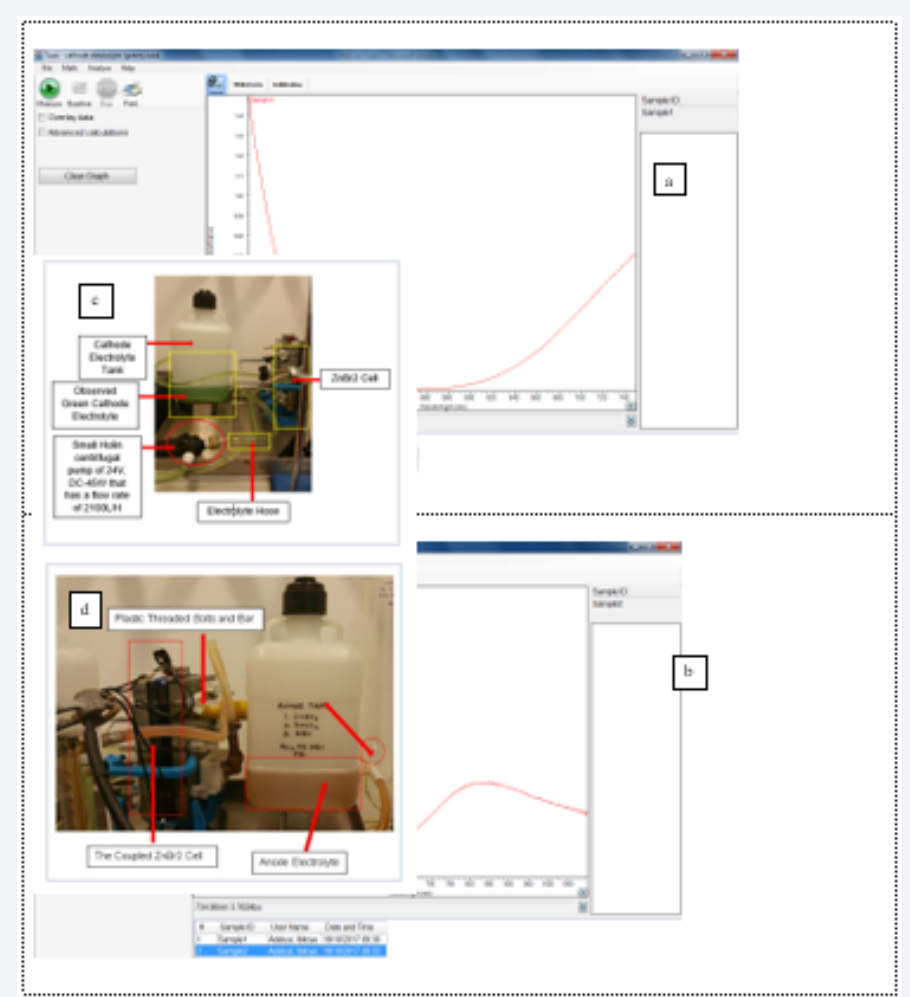

Figure 7:

a) First identified peak showing the presence of copper at a wavelength of $740 \mathrm{~nm}$.

b) Second identified peak showing the presence of copper at a wavelength of $900 \mathrm{~nm}$ with a UV-visible spectrophotometer device.

c) Observed green colour at the cathode-side electrolyte solution after charging the fabricated $\mathrm{ZnBr} 2$ battery cell severally at $1 \mathrm{~A}$ for 1800 secs.

d) Colourless anode-side electrolyte solution after charging the fabricated $\mathrm{ZnBr} 2$ battery cell severally at $1 \mathrm{~A}$ for $1800 \mathrm{Secs}$. 


\section{Trends in Technical \& Scientific Research}

As presented in Tables 3-5, the images of the mapped elements during the SEI, scanning of electrons images showed no hydrogen traces subsequently after charging the $\mathrm{ZnBr}_{2}$ battery cell at various charged and discharged amperes.

Table 3: Mapped elements after drying the particles after charged.

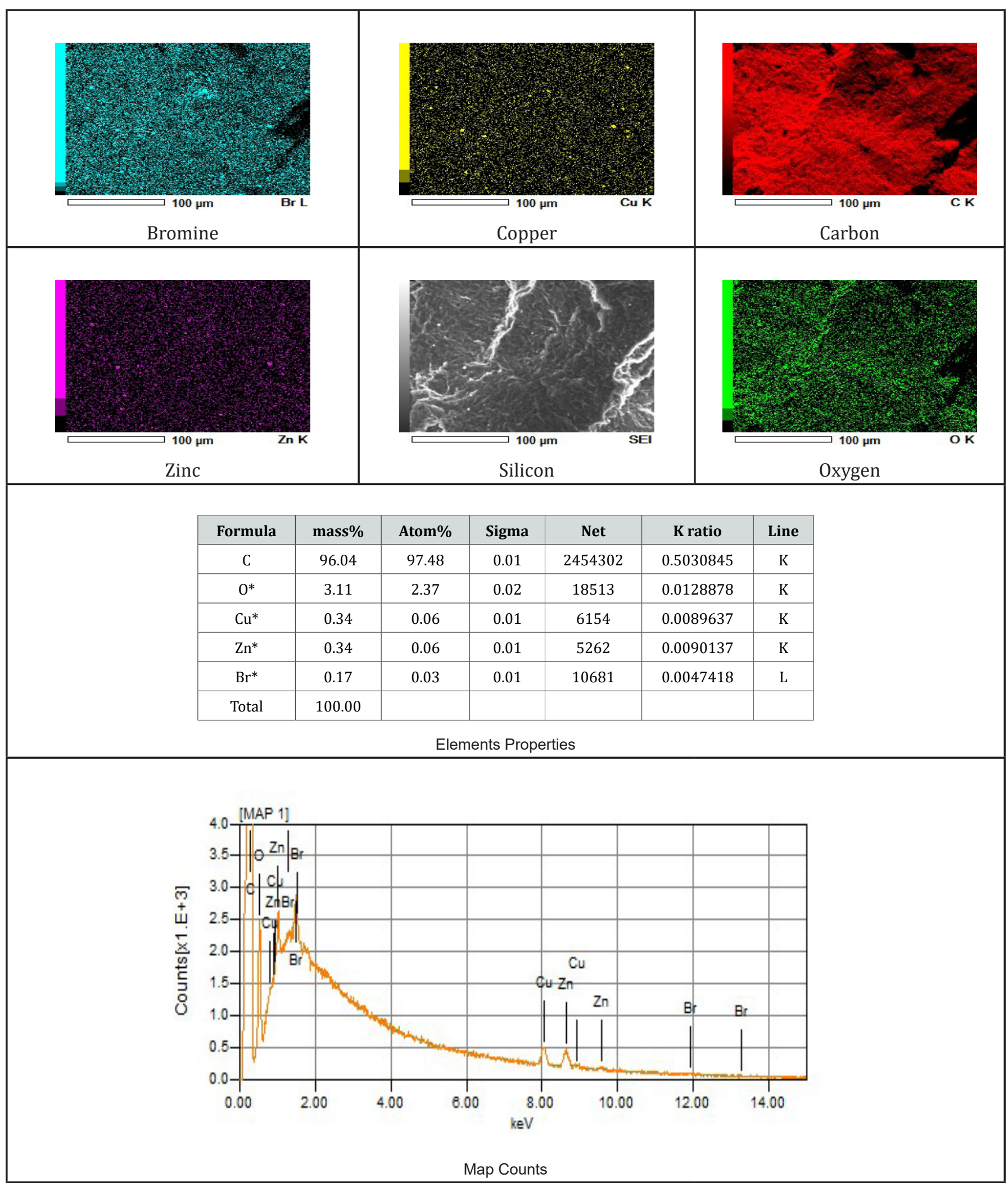




\section{Trends in Technical \& Scientific Research}

Table 4: Mapped elements after drying the particles after discharged.

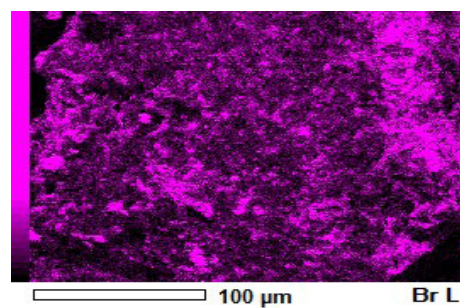

Bromine

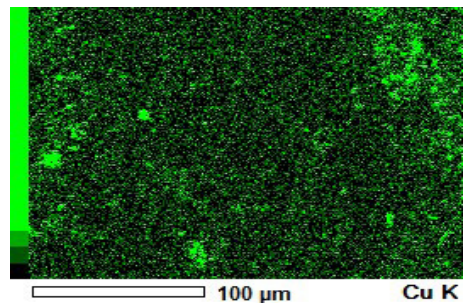

Copper

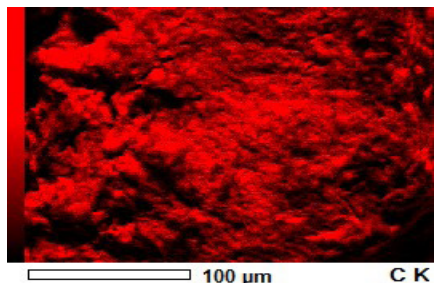

Carbon

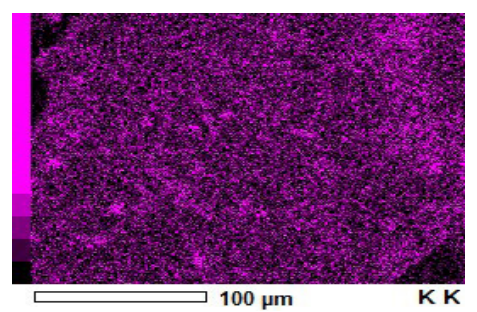

Potassium

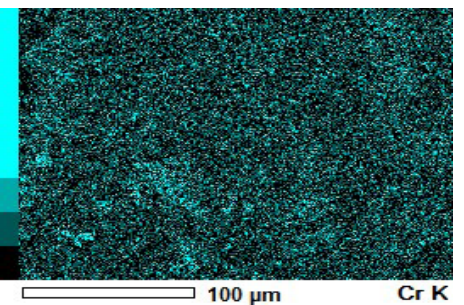

Chromium

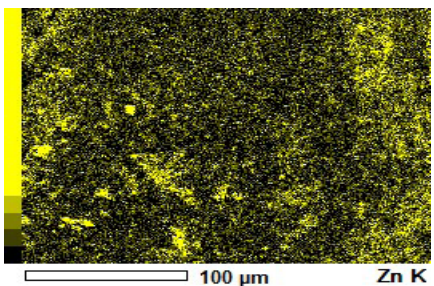

Zinc

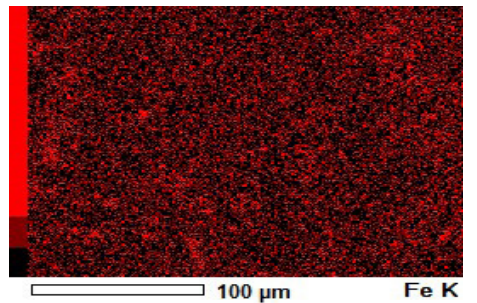

Iron

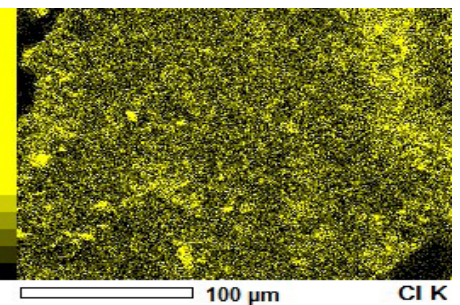

Chlorine

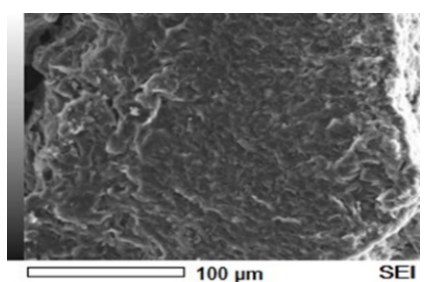

Silicon

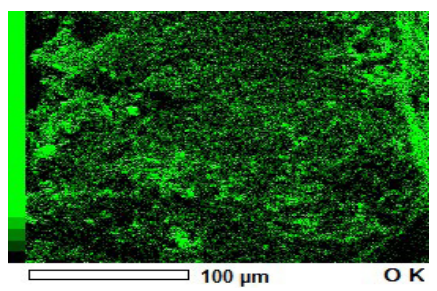

Oxygen

\begin{tabular}{|c|c|c|c|c|c|c|}
\hline Formula & mass\% & Atom\% & Sigma & Net & K ratio & Line \\
\hline $\mathrm{C}$ & 88.10 & 94.51 & 0.01 & 1956419 & 0.4010615 & $\mathrm{~K}$ \\
\hline $\mathrm{O}^{*}$ & 5.19 & 4.18 & 0.02 & 45690 & 0.0318090 & $\mathrm{~K}$ \\
\hline $\mathrm{Cl}$ & 0.33 & 0.12 & 0.00 & 42781 & 0.0141327 & $\mathrm{~K}$ \\
\hline $\mathrm{K}^{*}$ & 0.16 & 0.05 & 0.00 & 18229 & 0.0070554 & $\mathrm{~K}$ \\
\hline $\mathrm{Cr}^{*}$ & 0.09 & 0.02 & 0.01 & 5536 & 0.0036824 & $\mathrm{~K}$ \\
\hline $\mathrm{Fe}^{*}$ & 0.08 & 0.02 & 0.01 & 3483 & 0.0031057 & $\mathrm{~K}$ \\
\hline $\mathrm{Cu}^{*}$ & 0.78 & 0.16 & 0.01 & 20071 & 0.0292386 & $\mathrm{~K}$ \\
\hline $\mathrm{Zn}$ & 2.42 & 0.48 & 0.02 & 53916 & 0.0923618 & $\mathrm{~K}$ \\
\hline $\mathrm{Br}$ & 2.86 & 0.46 & 0.01 & 231046 & 0.1025811 & $\mathrm{~L}$ \\
\hline $\mathrm{Total}$ & 100.0 & 100.0 & & & & \\
\hline
\end{tabular}

Element Properties 


\section{Trends in Technical \& Scientific Research}

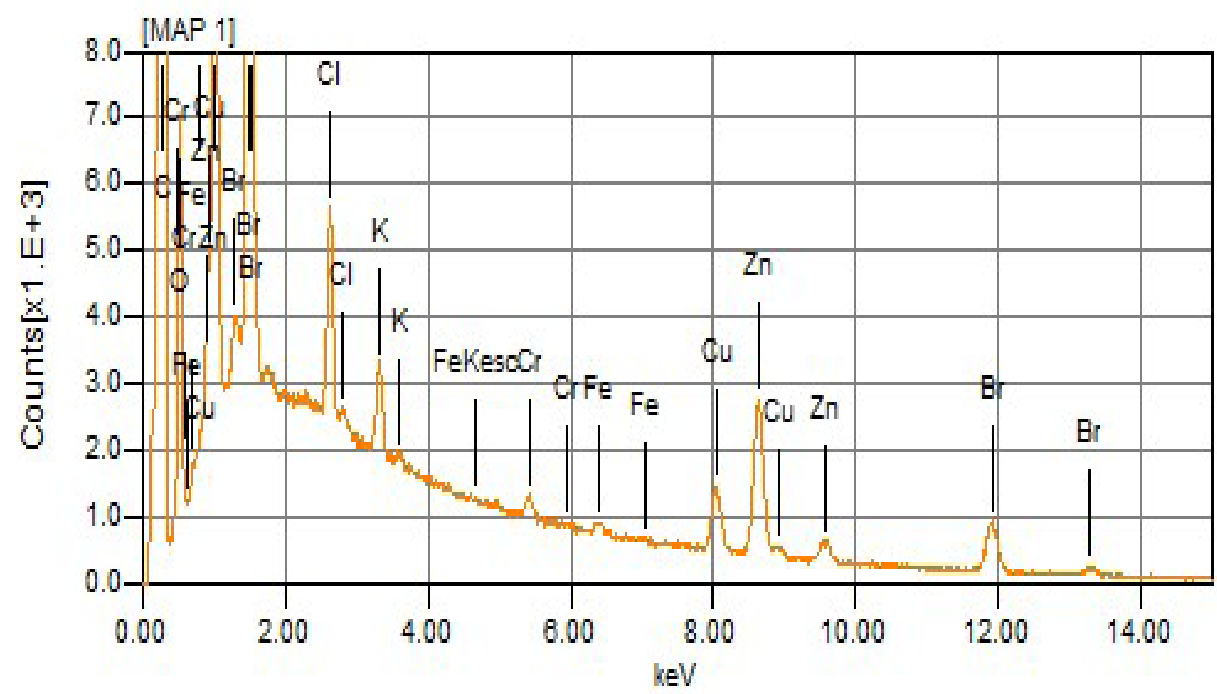

Elements Map Counts

Table 5: Mapped elements of charged and discharged after copper deposits.

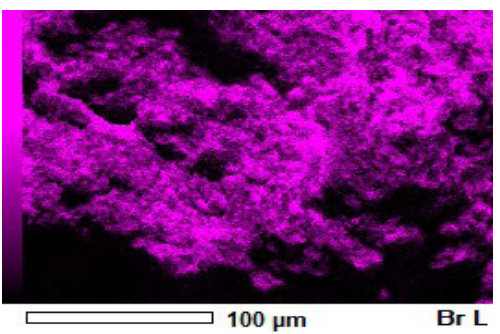

Bromine

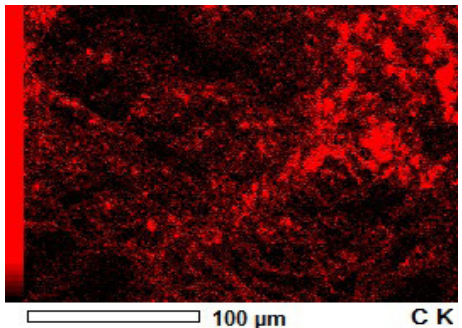

Carbon

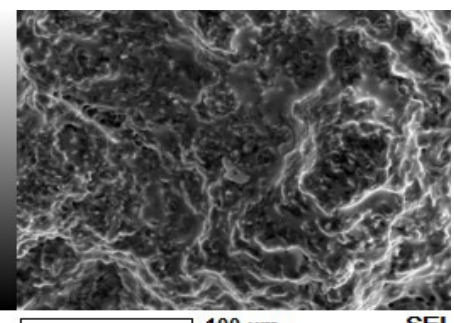

Selenium

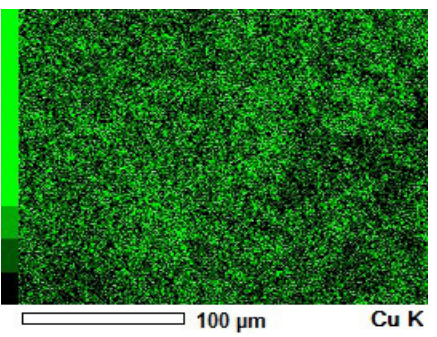

Copper

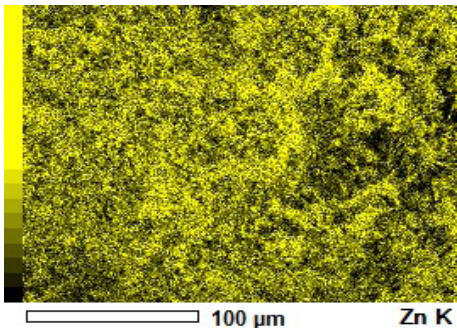

Zinc

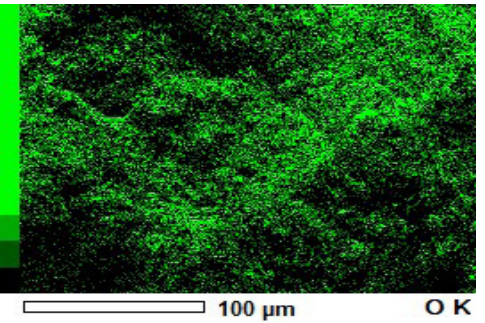

Oxygen

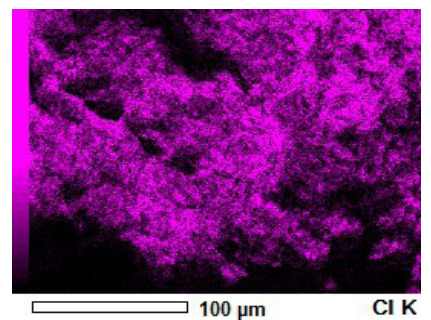

Chlorine

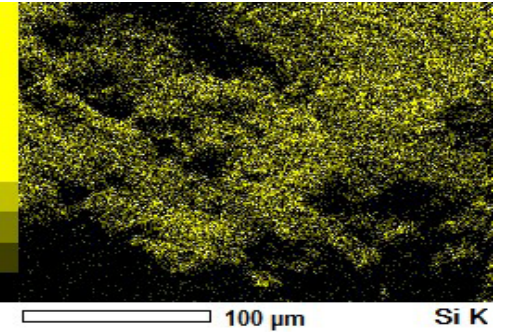

Silicon

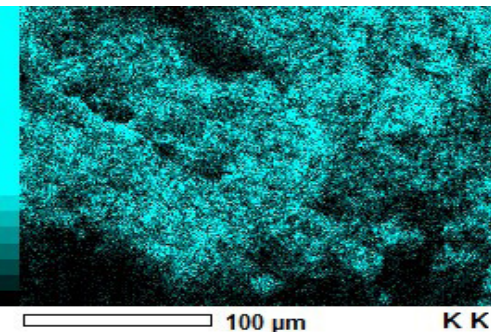

Potassium 


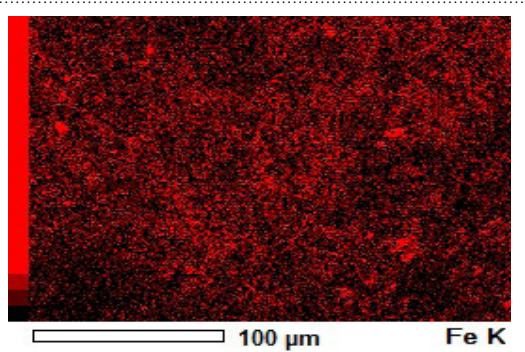

Iron

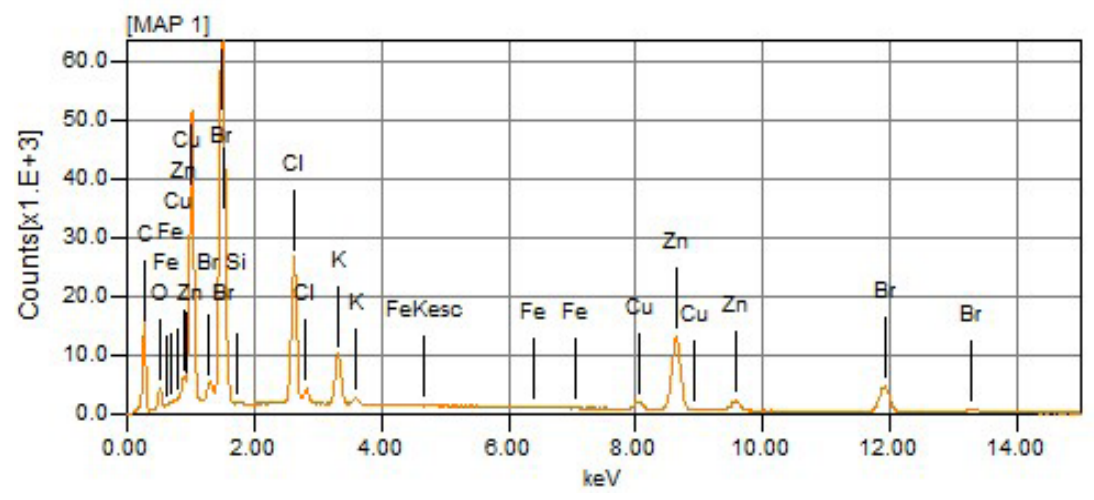

Map Counts

\begin{tabular}{|c|c|c|c|c|c|c|}
\hline Formula & mass\% & Atom\% & Sigma & Net & K ratio & Line \\
\hline $\mathrm{C}$ & 40.09 & 75.21 & 0.03 & 88864 & 0.0182154 & $\mathrm{~K}$ \\
\hline $\mathrm{O}^{*}$ & 3.39 & 4.78 & 0.02 & 23631 & 0.0164505 & $\mathrm{~K}$ \\
\hline $\mathrm{Si}$ & 0.05 & 0.04 & 0.01 & 2202 & 0.0005507 & $\mathrm{~K}$ \\
\hline $\mathrm{Cl}$ & 5.56 & 3.53 & 0.01 & 307391 & 0.1015378 & $\mathrm{~K}$ \\
\hline $\mathrm{K}$ & 2.23 & 1.29 & 0.01 & 118667 & 0.0459243 & $\mathrm{~K}$ \\
\hline $\mathrm{Fe}^{*}$ & 0.19 & 0.08 & 0.01 & 4808 & 0.0042868 & $\mathrm{~K}$ \\
\hline $\mathrm{Cu}$ & 1.80 & 0.64 & 0.02 & 27284 & 0.0397436 & $\mathrm{~K}$ \\
\hline $\mathrm{Zn}$ & 20.26 & 6.98 & 0.06 & 270830 & 0.4639136 & $\mathrm{~K}$ \\
\hline $\mathrm{Br}$ & 26.42 & 7.45 & 0.06 & 871135 & 0.3867394 & $\mathrm{~L}$ \\
\hline $\mathrm{Total}$ & 100.0 & 100.0 & & & & \\
\hline
\end{tabular}

Elements Properties

Zinc deposited within the anode reactor via SEM were viewed using different microns. Picture 1, observed as 100 microns has a sedimentary rock shape, photo 3 , viewed in 10 microns has high mossy deposits that look like zinc clusters. Picture 2 of 50 microns resemble silt sand that was sticky together, and photo 4 , was observed in 5 microns. Particles collected after discharging the stored energy by the battery cell were like the charged particles examined via SEM. Furthermore, the carbon fibre feeder electrode materials also contributed to the low current in between $(-300 \mathrm{~mA}$ to $300 \mathrm{~mA})$ that was observed continuously when the fabricated battery cell was charged and throughout its mode of operation. In the past, a similar magnificently SEM results have been achieved despite using the appropriate working electrodes materials, primary and secondary supporting electrolyte which also enhanced a good electrochemical behaviour [50].

\section{Charged and Dried Particles}

\section{Discharged and Dried Particles}

\section{Cu Electrodeposition at Charge and Discharge}

\section{UV-Visible Spectrometer Device and Peak Plots}

As presented in Figure 8, a UV-Vis spectroscopy laboratory device is a simple, quick, and not expensive measurable technique for measuring the amount of light absorbs by a chemical 
substance. See also Figure 7a-7c and Figure 9 for other results. The process can be carried out by gaging the light intensity passing through a sample in relation to the light intensity through a blank reference or sample. Multiple techniques can measure types of multiple samples, either in thin film, glass, liquids, or solids. UV-Vis Spectroscopy as a measuring device is suitable to know the transmitting, absorption and the functioning reflection of a material wavelength in the range of 190 nanometers to 1,100 manometers [51,52].

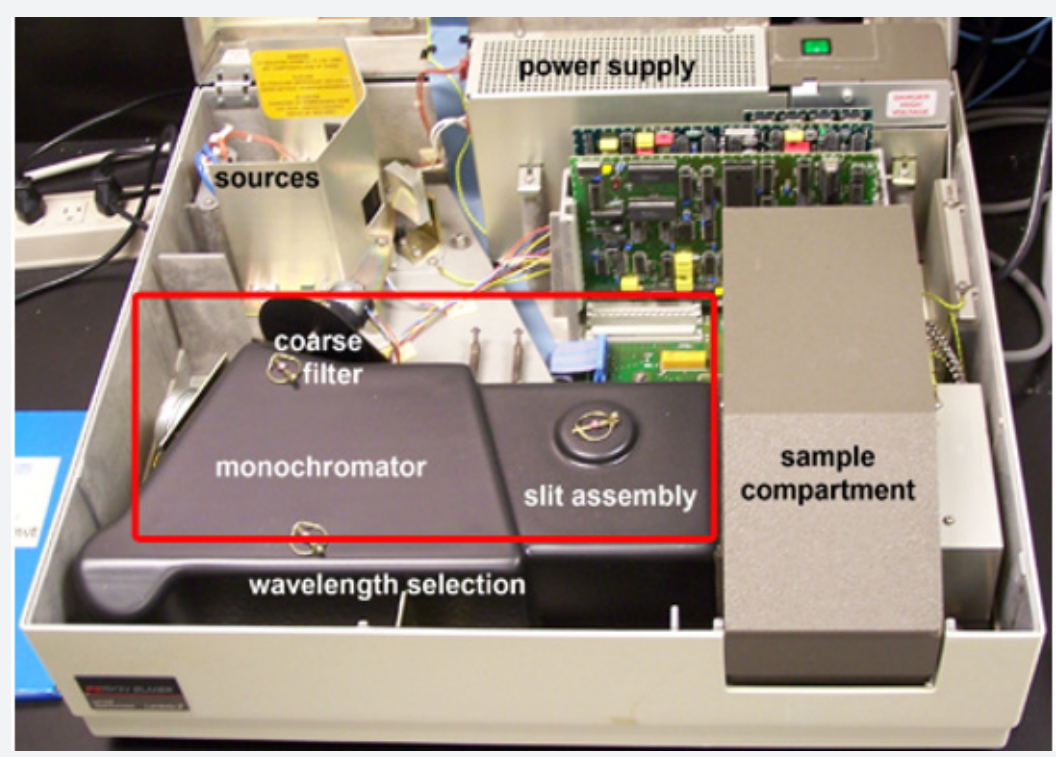

Figure 8: UV-Vis spectroscopy device [53].

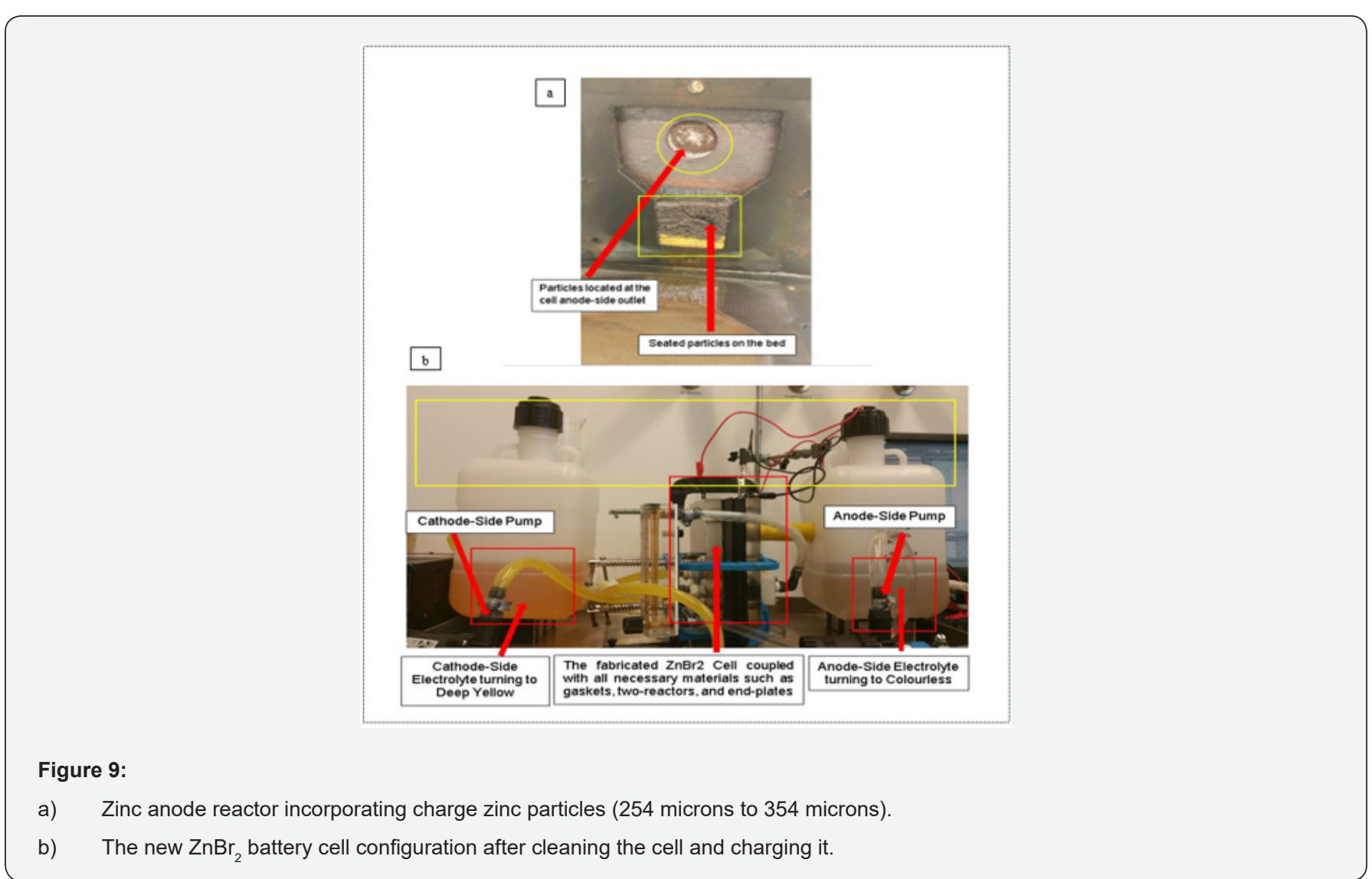


With a UV-Vis spectroscopy device, it was possible the observed brown deposits within the cathode electrolyte solution as copper by collecting some of this electrolyte solution in a small glass bottle after passing these charges to the cell: (1) 0.1 amps and -0.1 amps for 3600 secs and 800 secs (2) At 0.1 amps and -0.1 amps for 3500 secs and 200 secs and (3) At 0.25 amps for 3600 secs and -0.25 amps for 100 secs with 3 moles of $\mathrm{KBr}$ (535.51 grams), 1 mole of $\mathrm{KCl}$ (111.89 grams) as the cathode-side electrolyte solution and 3 moles of $\mathrm{ZnBr}_{2}$ (675 grams), $1 \mathrm{M}$ of $\mathrm{ZnCl}_{2}$ (205 grams), and 1 mole of $\mathrm{KCl}$ (111.826 grams) as the anode electrolyte solution $[53,54]$.

The cathode electrolyte solution contains 3 moles of $\mathrm{KBr}$ (535.51g), 1 mole of $\mathrm{KCl}$ (111.89g). The anode electrolyte solution contains 3 moles of $\mathrm{ZnBr}_{2}, 1$ mole of $\mathrm{KCl}$ and 1 mole of $\mathrm{ZnCl}_{2}$. Both electrolytes solution contained 24.1g of Sodium Bromoacetate acid and Bromoacetic acid and 240g of MEM-Sequestering agent.

\section{Conclusion and Future Work}

The fabricated $\mathrm{ZnBr}_{2}$ cell chemically converted to a $\mathrm{CuZn}_{2}$ battery cell due to the non-chemically fitted brass materials coupled to the fabricated battery cell according to the investigated brown deposits within the cathode-side electrolyte observed to be copper and further to the explored SEM analysis on some of the electrodeposited charged zinc particles incorporated within the anode-reactor. The outcome of the results encouraged interrupting the cell from operating further and led to pulling apart the cell components to be properly cleaned and the sieving separation technique carried out on the cathode and anode electrolyte solution due the escaped charged zinc-particles.

Furthermore, as previously mentioned the possibility to revert the cell back to a zinc-bromine battery cell from a copper-zinc battery cell had occurred by changing the brass fitting materials (BFM) to a plastic fitting material (PFM). The observed brown deposits which had converted the zinc-bromine batteries cell to a copper-zinc battery cell was only possible to be reverted to a zinc-bromine battery cells by carrying out repeatedly a filtration process to separate the sediments observed from the anode and cathode electrolyte solution.

Initially by not fabricating the Nafion membrane size to the actual length and cell breadth size (190mm*190mm), had supported allowing the anode and cathode electrolyte to mix. Therefore, fabricating the membrane size to a cell shape will prevent any future occurrence from allowing any cross-mixing of any anode-side and cathode-side electrolyte.

By using a UV-visible spectrophotometer device to detect why the cathode-side electrolyte did not change to a reddish brown or yellow colour during the charge rate and discharged rate after identifying a dark green coloured electrolyte at the cathode-side cell; which was recognized as copper at a wavelength of $900 \mathrm{~nm}$ and with two peaks (see Figure 7a \& 7b) had also supported having the establishment of a good redox reaction according to the electrochemical results according to the experimental observation. Furthermore, see Figures $1 \& 7 \mathrm{~b}$. Therefore, identifying the chemistry behind the electrolyte colour had further helped.

The presence of oxygen $\left(\mathrm{O}_{2}\right)$ was agreed to have occurred because the cell was exposed before coupling it and due to the presence of $\mathrm{H} 2 \mathrm{O}$. Silicon has originated due to the applied adhesive glue to prevent leakages. Chromium (Cr), Iron (Fe) and carbon (C) were both produced due to the coupled anode-inlet and anodeoutlet pipe steel materials and brass fittings that were not chemical resistance. The anode and cathode inlets and outlets brass fittings materials had supported the origination of the identified selenium element during the chemical reaction. Selenium as non-metallic chemical elements in the group xvi of the periodic table could conducts electricity better in the light than in the dark and used in photocells. It was not peculiar by identifying some potassium elements during the SEM since the cell electrolytes consisted of some added salt.

\section{References}

1. Adelusi I, Victor AC, Andrieux F, Dawson R (2020) Practical Development of a $\mathrm{ZnBr}_{2}$ Flow Battery with a Fluidized Bed Anode ZincElectrode. Journal of The Electrochemical Society 167(5): 050504.

2. Yang H, Park J, Ra H, Jin CS, Yang J (2016) Critical rate of electrolyte circulation for preventing zinc dendrite formation in a zinc bromine redox flow battery. J Power Sources 325: 446-452.

3. Lin H, Bai L, Han X, Zhang Y, Shi J (2018) Pyrolytic carbon felt electrode Inhibits formation of zinc dendrites in zinc bromine flow batteries. International Journal of Electrochemical Science 13(12): 12049-12061.

4. Conny JM (2013) Internal composition of atmospheric dust particles from focused ion-beam scanning electron microscopy. Environmental Science and Technology 47(15): 8575-8581.

5. Jain V, Kalo L, Kumar D, Pant HJ, Upadhyay RK (2017) Experimental and numerical investigation of liquid-solid binary fluidized beds: Radioactive particle tracking technique and dense discrete phase model simulations. Particuology 33: 112-122.

6. Adamczyk WP, Węcel G, Klajny M, Kozołub P, Klimanek A, et al. (2014) Modeling of particle transport and combustion phenomena in a largescale circulating fluidized bed boiler using a hybrid Euler-Lagrange approach. Particuology 16: 29-40.

7. Andrews MJ, O Rourke PJ (1996) The multiphase particle-in-cell (MPPIC) method for dense particulate flows. International Journal of Multiphase Flow 22(2): 379-402.

8. Asif M (1998) A simple predictive model of layer inversion in binary solid-liquid fluidized beds. Journal of Chemical Technology \& Biotechnology 71(4): 340-344.

9. Barghi S, Briens CL, Bergougnou MA (2003) Mixing and segregation of binary mixtures of particles in liquid-solid fluidized beds. Powder Technology 131(2-3): 223-233.

10. Carlos CR, Richardson JF (1968) Solids movement in liquid fluidised beds-I Particle velocity distribution. Chemical Engineering Science 23(8): 813-824.

11. Chavan P, Joshi J (2008) Analysis of Particle Segregation and Intermixing in Solid-Liquid Fluidized Beds. Ind Eng Chem Res 47(21): 8458-8470. 
12. Chen J, Kemoun A, Al Dahhan MH, Duduković MP, Lee DJ, et al. (1999) Comparative hydrodynamics study in a bubble column using computer-automated radioactive particle tracking (CARPT)/computed tomography (CT) and particle image velocimetry (PIV). Chemical Engineering Science 54(13-14): 2199-2207.

13. Wang F, Fan LS (2011) Gas-Solid Fluidization in Mini- and Microchannels. Industrial \& Engineering Chemistry Research 50(8): 47414751.

14. Xiao Y, Roberts DJ, Zuo G, Badruzzaman M, Lehman GS (2010) Characterization of microbial populations in pilot-scale fluidized-bed reactors treating perchlorate- and nitrate-laden brine. Water Research 44(14): 4029-4036.

15. Venkatesan AK, Sharbatmaleki M, Batista JR (2010) Bioregeneration of perchlorate-laden gel-type anion-exchange resin in a fluidized bed reactor. Journal of Hazardous Materials 177(1-3): 730-737.

16. Sahu A, Conneely T, Nüsslein K, Ergas S (2009) Biological Perchlorate Reduction in Packed Bed Reactors Using Elemental Sulfur. Environmental Science \& Technology 43(12): 4466-4471.

17. Thomas PJ, Stansfield GL, Vanitha PV (2011) Nanoparticles. Annu Rep Prog Chem, Sect A: Inorg Chem 107: 505-518.

18. Kundu P, Anumol EA, Nethravathi C, Ravishankar N (2011) Existing and emerging strategies for the synthesis of nanoscale heterostructures. Phys Chem Chem Phys 13(43): 19256-19269.

19. Matuttis HG (2014) Understanding the discrete element method: simulation of non-spherical particles for granular and multi-body systems. In: Chen JF, (ed.).

20. Deng X, Zheng K, Davé RN (2018) Discrete element method-based analysis of mixing and collision dynamics in adhesive mixing process. Chemical Engineering Science 190: 220-231.

21. Seelen LJH, Padding JT, Kuipers JAM (2018) A granular Discrete Element Method for arbitrary convex particle shapes: Method and packing generation. Chemical Engineering Science 189: 84-101.

22. Khawaja H (2016) CFD-DEM Simulation of Minimum Fluidisation Velocity in Two Phase Medium. International Journal of Multiphysics $5(2)$.

23. Raoelison RN (2017) Analytical description of solid particles kinematics due to a fluid flow and application to the depiction of characteristic kinematics in cold spraying. Powder Technology 319: 191-203.

24. Wang S, Li X, Lu H, Yu L, Ding J, et al. (2009) DSMC prediction of granular temperatures of clusters and dispersed particles in a riser. (Report). Powder Technology 192(2): 225-233.

25. Wills Barry A, Finch James A (2016) Modeling and Characterization. $8^{\text {th }}$ Edition ed: Elsevier p. 1.

26. Freyn A, Kleftogiannis I, Pichard JL (2008) Scanning gate microscopy of a nanostructure where electrons interact. Physical review letters 100(22): 226802

27. Ortalan V, Zewail AH (2011) 4D scanning transmission ultrafast electron microscopy: Single-particle imaging and spectroscopy. Journal of the American Chemical Society 133(28): 10732-10735.

28. Crimp MA (2006) Scanning electron microscopy imaging of dislocations in bulk materials, using electron channeling contrast. Microsc Res Tech 69(5): 374-381.

29. Luo Z (2016) A practical guide to transmission electron microscopy. Advanced microscopy. First edition, 2.

30. Rivacoba A, Zabala N, Echenique P (1992) Theory of Energy-Loss in Scanning-Transmission Electron-Microscopy of Supported Small Particles. Phys Rev Lett 69(23): 3362-3365.
31. Richman JD, Livi KJT, Geyh AS (2011) A scanning transmission electron microscopy method for determination of manganese composition in welding fume as a function of primary particle size. Journal of Aerosol Science 42(6): 408-418.

32. Alonso Mori R, Kern J, Gildea RJ, Sokaras D, Weng TC, et al. (2012) Energy-dispersive X-ray emission spectroscopy using an X-ray freeelectron laser in a shot-by-shot mode. Proceedings of the National Academy of Sciences of the United States of America 109(47): 1910319107.

33. Chee AKW, Broom RF, Humphreys CJ, Bosch EGT (2011) A quantitative model for doping contrast in the scanning electron microscope using calculated potential distributions and Monte Carlo simulations. Journal of Applied Physics 109(1).

34. Kreith J, Strunz T, Fantner EJ, Fantner GE, Cordill MJ (2017) A versatile atomic force microscope integrated with a scanning electron microscope. Review of Scientific Instruments 88(5): 053704.

35. Bouwer J, Deerinck T, Bushong E, Astakhov V, Ramachandra R, et al. (2016) Deceleration of probe beam by stage bias potential improves resolution of serial block-face scanning electron microscopic images. Advanced Structural and Chemical Imaging 2(1): 1-13.

36. Moran CH, Xia X, Xia Y (2013) Improving correlated SERS measurements with scanning electron microscopy: an assessment of the problem arising from the deposition of amorphous carbon. Phys Chem Chem Phys 15(15): 5400-5406.

37. Konvalina I, Hovorka M, Wandrol P, Mika F, Mllerov I (2007) Strategies for Collection of Secondary Electrons in the SEM. Microsc Microanal 13(S03): 78-79.

38. Yang DS, Mohammed OF, Zewail AH (2010) Scanning ultrafast electron microscopy. Proceedings of the National Academy of Sciences of the United States of America 107(34): 14993-14998.

39. Richards RG, Wieland M, Textor M (2000) Advantages of stereo imaging of metallic surfaces with low voltage backscattered electrons in a field emission scanning electron microscope. Journal of Microscopy 199(2): 115-123.

40. Kawagoe T, Tamura E, Suzuki Y, Koike K (2002) Scattering of surfacestate electrons by the monatomic step in Fe (001): Differential conductivity imaging by scanning tunneling microscopy. Physical Review B - Condensed Matter and Materials Physics 65(2): 244061244065.

41. Valkenburg JA, Woldringh CL, Brakenhoff GJ, van der Voort HT, Nanninga N (1985) Confocal scanning light microscopy of the Escherichia coli nucleoid: comparison with phase-contrast and electron microscope images. The Journal of Bacteriology 161(2): 478-483.

42. Frank L, Hovorka M, Konvalina I, Mikmeková Š, Müllerová I (2011) Very low energy scanning electron microscopy. Nuclear Inst and Methods in Physics Research A 645(1): 46-54.

43. Loussert Fonta C, Humbel BM (2015) Correlative microscopy. Archives of Biochemistry and Biophysics 581: 98-110.

44. Schulson E (1977) Electron channelling patterns in scanning electron microscopy. Journal of Materials Science 12(6):1071-1087.

45. Jany BR, Janas A, Krok F (2017) Retrieving the Quantitative Chemical Information at Nanoscale from Scanning Electron Microscope Energy Dispersive X-ray Measurements by Machine Learning. Nano letters 17(11): 6520-6525

46. Ogura T (2010) Direct observation of unstained wet biological samples by scanning-electron generation X-ray microscopy. Biochemical and Biophysical Research Communications 391(1): 198-202.

47. Papa JP, Pereira CR, De Albuquerque VHC, Silva CC, Falcão AX, et al. (2011) Precipitates segmentation from scanning electron microscope 
images through machine learning techniques. Lecture Notes in Computer Science (including subseries Lecture Notes in Artificial Intelligence and Lecture Notes in Bioinformatics) 6636: 456-468.

48. Zaluzec NJ (2014) Analytical Formulae for Calculation of X-Ray Detector Solid Angles in the Scanning and Scanning/Transmission Analytical Electron Microscope 20(4): 1318-1326.

49. Inada H, Taniguchi Y, Yotsuji T, Hirayama Y, Dobashi T, et al. (2016) Aberration Corrected Analytical Scanning and Transmission Electron Microscope for High-Resolution Imaging and Analysis for Multi-User Facilities. Microscopy and Microanalysis 22(S3): 32-33.

50. Gobinath P, Rajarathnam MS, Xihe S, Anthony MV (2016) The Influence of Supporting Electrolytes on Zinc Half-Cell Performance in Zinc/ Bromine Flow Batteries. Journal of The Electrochemical Society 163(1): A5112-A7.
51. Instruments E (2012) UV/ Visible Spectroscopy.

52. Thomas MJK (1996) Ultraviolet and visible spectroscopy. In: Ando DJ, $2^{\text {nd }}$ ed., editor: Published on behalf of ACOL University of Greenwich by J Wiley.

53. Stone DC (2012) Molecular Spectroscopy Resources.

54. Rodenburg C, Jepson MAE, Bosch E (2010) Advantages of Energy Selective Secondary Electron Detection in SEM. Microsc Microanal 16(S2): 622-623.

Yasin FS, Harvey TR, Chess JJ, Pierce JS, Ophus C, et al. (2018) Probing Light Atoms at Subnanometer Resolution: Realization of Scanning Transmission Electron Microscope Holography. Nano letters 18(11): 7118-7123.

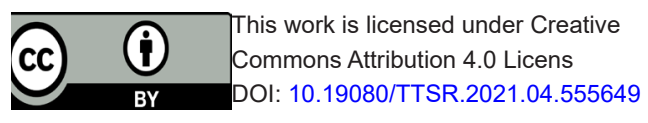

\section{Your next submission with Juniper Publishers will reach you the below assets}

- Quality Editorial service

- Swift Peer Review

- Reprints availability

- E-prints Service

- Manuscript Podcast for convenient understanding

- Global attainment for your research

- Manuscript accessibility in different formats

( Pdf, E-pub, Full Text, Audio)

- Unceasing customer service

Track the below URL for one-step submission https://juniperpublishers.com/online-submission.php 